\title{
The influence of crown-to-implant ratio on marginal bone loss: a narrative review
}

\author{
Adolfo Di Fiore, Francesco Maniero, Edoardo Stellini \\ Department of Neurosciences, School of Dentistry, Section of Prosthodontics and Digital Dentistry, University of Padova, Padova, Italy \\ Contributions: (I) Conception and design: All authors; (II) Administrative support: All authors; (III) Provision of study materials or patients: All \\ authors; (IV) Collection and assembly of data: All authors; (V) Data analysis and interpretation: All authors; (VI) Manuscript writing: All authors; (VII) \\ Final approval of manuscript: All authors. \\ Correspondence to: Adolfo Di Fiore. Department of Neurosciences, School of Dentistry, Section of Prosthodontics and Digital Dentistry, University of \\ Padova, Padova, Italy. Email: adolfo.difiore@unipd.it.
}

\begin{abstract}
Background and Objective: Marginal bone loss (MBL) is considered a fundamental criterion for implant success. Many factors may influence MBL, but it is still not clear how MBL is influenced by crown-to-implant ratio (C/I-R). In addition, the introduction of short implants, to avoid bone augmentation procedure, lead to ratios higher and higher. The aim of this study is to elucidate about the role of high C/I-R on MBL.

Methods: The articles were identified through MEDLINE database (via PubMed) and checking references. After the selection, 20 articles were included in the review.

Key Content and Findings: The highest follow-up among the selected studies was 16 years for the retrospective studies and 5 years for the perspective studies. The highest ratio reported was 2.53 .

Conclusions: In conclusion, it is possible to state that C/I-R not exceed 2.2 did not influence the manifestation of biological complications and lead to a not significant MBL.
\end{abstract}

Keywords: Crown-to-implant ratio (C/I-R); marginal bone loss (MBL); short implants

Received: 01 September 2020; Accepted: 15 October 2020; Published: 20 November 2020.

doi: $10.21037 /$ fomm-20-57

View this article at: http://dx.doi.org/10.21037/fomm-20-57

\section{Introduction}

Dental implants are considered nowadays a reliable solution to replace teeth. High implants and prosthesis survival rates (above $98 \%$ after 5 years) were achieved $(1,2)$. To consider successful an implant therapy the criteria at implant level are: absence of pain, bone loss at 1 st year $<1.5 \mathrm{~mm}$, annual bone loss $<0.2 \mathrm{~mm}$ thereafter, no radiolucency, no mobility, no infection (3). Therefore, marginal bone loss (MBL) represents a favourable factor for long-term implant stability (4). Unfavourable crown-to-implant ratio (C/I-R), occlusal overload, occlusal table width, off-axis loading and cantilevers are factors that play a role in the failure of prosthetic implant therapy (5-7). The influence of cantilever (8), occlusal overload (9), and off-axis loading in prosthetic complications are largely demonstrated.

However, the role of C/I-R on MBL is still unclear. C/
I-R is the application in implantology of the prosthodontics parameter of crown-to-root ratio. Ideally, the ratio between the crown and the root should be 1:2, and a minimum of 1:1 for a tooth abutment is recommended. To avoid unfavourable C/I-R, these prosthetic concepts have been used in implant dentistry. C/I- $\mathrm{R}$ is calculated as the ratio between the crown and implant lengths. We can distinguish two different C/I-R:

* Anatomical ratio is the ratio between the distance from the apex to the shoulder of the implant, and the distance from the shoulder of the implant to the end of the crown;

* Clinical ratio is the ratio between the distance from the apex to the bone level, and the distance from the bone level to the end of the crown.

In literature there are evidences that attest both the presence $(10)$ and the absence $(11,12)$ of a relationship between MBL and C/I-R, and one studies even deducted 


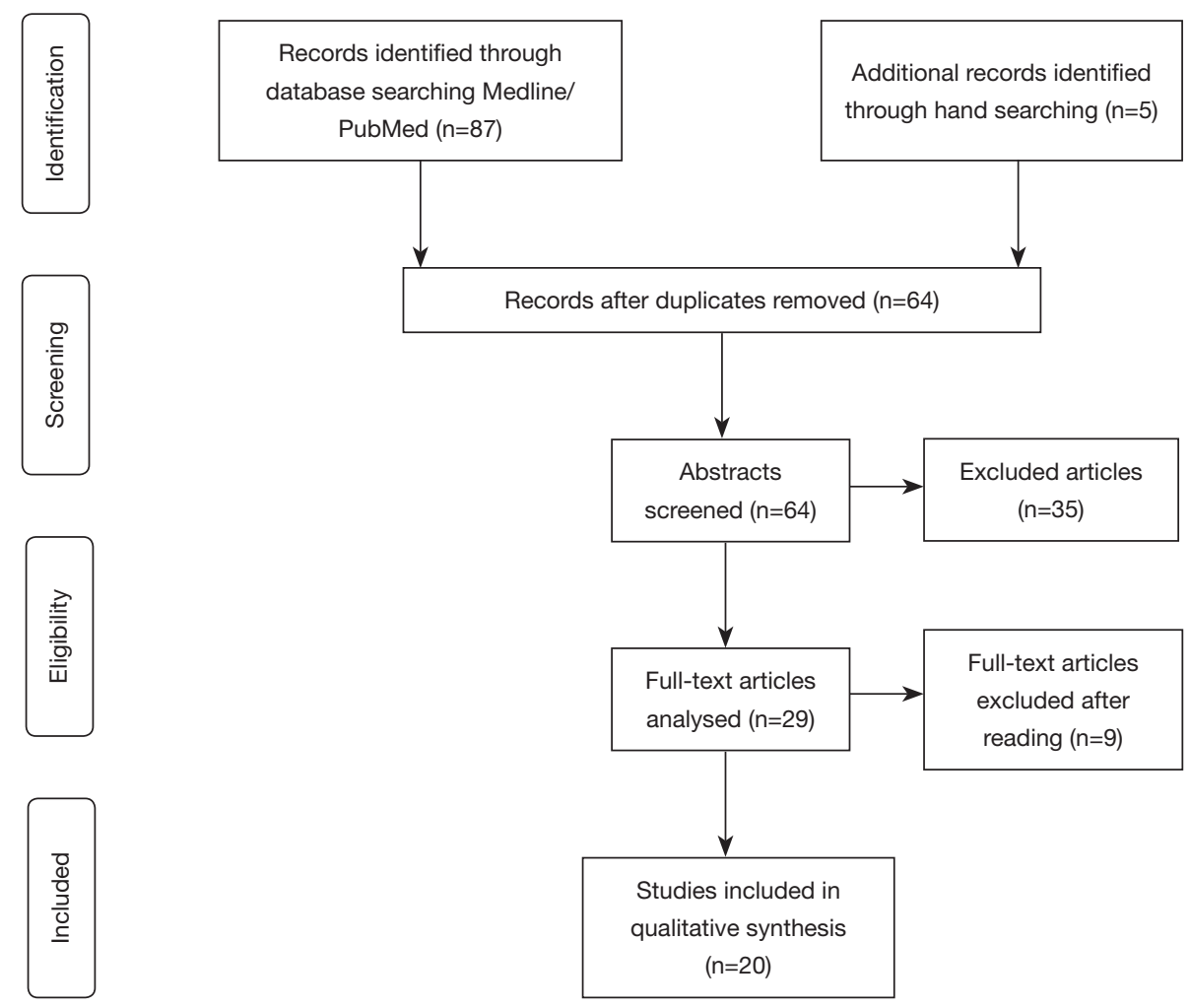

Figure 1 Flowchart of study selection.

that high CI might provide a protective effect on bone loss (13). In addition, the introduction of short implant, to avoid bone augmentation procedure, lead to C/I-R higher and higher. A security threshold should be investigated to avoid biological complication and to guarantee the success of the therapy. The aim of this study is to elucidate about the role of C/I-R on MBL. We present the following article in accordance with the Narrative Review reporting checklist (available as https://fomm.amegroups.com/article/ view/10.21037/fomm-20-57/rc).

\section{Methods}

The articles were identified through MEDLINE database (via PubMed) combined the key words: "crown-implant ratio", "marginal bone loss", "alveolar bone loss", "short implants". The search was supplemented checking references of the relevant review articles. The studies had to meet the following requirement:

* At least 1 year follow-up;

* Mean C-I/R should be reported;

* Outcome measures should include at least bone changes;

* Publication must be reporting in the English.

The selection path of the articles is shown in Figure 1.

\section{Discussion/summary}

The primary selection identified 87 studies for the MEDLINE search. Checking of relevant reviews revealed five additional articles that met the inclusion criteria. After having removed duplicates and analysed titles and abstracts, 58 studies were excluded because they did not meet the inclusion criteria. The remaining 29 papers were evaluated by full-text analysis. Nine articles were finally excluded after full-text reading due to lack of information as marginal bone changes and C/I-R measurement. Characteristics of the selected studies are shown in Tables 1 and 2. Anitua et al. (14) in a retrospective study analysed 45 implants with a mean C/I-R of 2.4. The mean MBL reported was $1.01 \mathrm{~mm}$ for mesial bone, $0.89 \mathrm{~mm}$ for distal bone. Birdi et al. (15) studied 309 implants in a retrospective study. The mean $\mathrm{C} / \mathrm{I}-\mathrm{R}$ reported was 2.0 and the MBL was $0.2 \mathrm{~mm}$. Blanes et al. (16) in a perspective study analyzed 109 implants. 
Table 1 Studies included in the review

\begin{tabular}{|c|c|c|c|c|c|c|}
\hline Article & $\begin{array}{l}\text { Years of } \\
\text { publication }\end{array}$ & $\begin{array}{c}\mathrm{C} / \mathrm{l}-\mathrm{R} \\
\text { considered }\end{array}$ & Mean C/I-R & Mean CHS & Survival rate & Marginal bone changes \\
\hline Anitua et al. & 2014 & Clinical & 2.4 (1.5 to 3.69$)$ & $\begin{array}{c}17.05 \pm 3.05 \mathrm{~mm} \\
(11.2 \text { to } \\
25.4 \mathrm{~mm})\end{array}$ & $100 \%$ & $\begin{array}{c}\text { Mesial bone loss } 1.01 \pm 0.68 \mathrm{~mm} \text { (range } 0 \\
\text { to } \\
3.49 \mathrm{~mm} \text { ); distal bone loss } 0.89 \pm 0.7 \mathrm{~mm} \\
\text { (range } 0 \text { to } 3.86 \mathrm{~mm} \text { ) }\end{array}$ \\
\hline Blanes et al. & 2007 & Clinical & $1.77 \pm 0.56 \mathrm{~mm}$ & $\begin{array}{c}\text { Anatomical } \\
\text { crown length: } \\
9.57 \pm 2.6 \\
\text { mm; clinical } \\
\text { crown length: } \\
13.57 \pm 2.73 \mathrm{~mm}\end{array}$ & $\begin{array}{l}\text { Group ratio } \\
\text { >2 mm: } \\
94.1 \%\end{array}$ & $\begin{array}{l}\text { Group A (C/I-R: 0-0.99): }-0.35 \pm 0.27 \mathrm{~mm} \text {; } \\
\text { Group B (C/l-R: } 1-1.99):-0.03 \pm 0.15 \mathrm{~mm} \text {; } \\
\quad \text { Group C (C/l-R >2): }-0.02 \pm 0.26 \mathrm{~mm}\end{array}$ \\
\hline Hadzik et al. & 2018 & Anatomical & 1.69 & - & - & $-0.34 \pm 0.24 \mathrm{~mm}$ \\
\hline $\begin{array}{l}\text { Hingsammer } \\
\text { et al. }\end{array}$ & 2017 & Clinical & 1.70 (SD: 0.48) & $\begin{array}{l}9.9 \mathrm{~mm}(\mathrm{SD}: \\
1.24 \mathrm{~mm} ; \\
\text { range: } 8.1-12.4 \\
\mathrm{~mm})\end{array}$ & $97.3 \%$ & $-0.71 \mathrm{~mm}(\mathrm{SD}: 0.74 \mathrm{~mm})$ \\
\hline Lee et al. & 2012 & Clinical & $1.06 \pm 0.42$ & - & - & $-0.93 \pm 0.15 \mathrm{~mm}$ (range, 0.05 to $1.89 \mathrm{~mm})$ \\
\hline $\begin{array}{l}\text { Malchiodi } \\
\text { et al. }\end{array}$ & 2014 & $\begin{array}{l}\text { Clinical and } \\
\text { anatomical }\end{array}$ & $\begin{array}{l}\text { Anatomical: } 1.84 \pm 0.65 \\
\text { (range: } 0.86-4.28 \text { ); } \\
\text { Clinical: } 2.08 \pm 0.80 \\
\text { (range: } 0.95-4.80 \text { ) }\end{array}$ & - & $98.1 \%$ & $-0.48 \pm 0.29 \mathrm{~mm}$ \\
\hline Nunes et al. & 2016 & Clinical & $2.53 \pm 0.79$ & $\begin{array}{l}12.7 \mathrm{~mm} \text { (range } \\
11.94 \text { to } 19.99)\end{array}$ & $100 \%$ & $-0.67 \pm 0.63 \mathrm{~mm}$ \\
\hline Pieri et al. & 2012 & Clinical 1 & $\begin{array}{c}1.94 \pm 0.46 \text { (range } 1.31 \text { to } \\
3.12 \text { ) }\end{array}$ & $\begin{array}{l}11.16 \pm 2.72 \mathrm{~mm} \\
\text { (range } 7.42 \text { to } \\
17.34)\end{array}$ & $96.8 \%$ & $-0.60 \pm 0.13 \mathrm{~mm}$ \\
\hline Ramaglia et al. & 2019 & Anatomical & $\begin{array}{l}1.08(\mathrm{C} / \mathrm{I}-\mathrm{R} \text { minimum } \\
\text { value }=0.58 ; \mathrm{C} / \mathrm{I}-\mathrm{R} \\
\text { maximum value }=2.25)\end{array}$ & - & $100 \%$ & $\begin{array}{c}\mathrm{C} / \mathrm{I}-\mathrm{R} \leq 1:-0.653 \pm 0.58 \mathrm{~mm} ; \mathrm{C} / \mathrm{I}-\mathrm{R}>1 \mathrm{:} \\
-0.287 \pm 0.26 \mathrm{~mm}\end{array}$ \\
\hline
\end{tabular}

Table 1 (continued) 
Table 1 (continued)

\begin{tabular}{|c|c|c|c|c|c|c|}
\hline Article & $\begin{array}{c}\text { Years of } \\
\text { publication }\end{array}$ & $\begin{array}{c}\mathrm{C} / \mathrm{I}-\mathrm{R} \\
\text { considered }\end{array}$ & Mean C/I-R & Mean CHS & Survival rate & Marginal bone changes \\
\hline Rossi et al. & 2016 & Clinical & $\begin{array}{c}\text { Test: } 1.55 \text { (1.02 to } 2.53) ; \\
\text { Control: } 0.97 \text { (0.58 to } \\
1.40)\end{array}$ & $\begin{array}{c}\text { Test: } 7.7 \pm \\
2.0 \mathrm{~mm}(4.5 \\
\text { to } 12 \mathrm{~mm}) ; \\
\text { Control: } 7.3 \pm \\
1.9 \mathrm{~mm}(4.6 \text { to } \\
11 \mathrm{~mm})\end{array}$ & $\begin{array}{l}\text { Test: } 86.7 \% \text {; } \\
\text { Control: } \\
96.7 \%\end{array}$ & $\begin{array}{c}\text { Between the surgery and prosthesis } \\
\text { delivery: Test: }-0.38 \mathrm{~mm} \text {; Control: }-0.36 \\
\text { mm. After } 5 \text {-year: Test: }-0.14 \mathrm{~mm} \text {; Control: } \\
-0.18 \mathrm{~mm}\end{array}$ \\
\hline $\begin{array}{l}\text { Schneider } \\
\text { et al. }\end{array}$ & 2012 & $\begin{array}{l}\text { Clinical and } \\
\text { anatomical }\end{array}$ & $\begin{array}{l}\text { Anatomical: } 1.04 \pm 0.26 \\
\text { (0.59 to } 2.01) \text {; Clinical: } \\
148 \pm 0.42(0.82 \text { to } 3.24)\end{array}$ & - & $95.8 \%$ & $-0.008 \mathrm{~mm}(\mathrm{SD} 0.74 \mathrm{~mm})$ \\
\hline $\begin{array}{l}\text { Sharmann } \\
\text { et al. }\end{array}$ & 2016 & Clinical & $\begin{array}{c}\text { Test: } 1.48 \pm 0.33 \text {; Control: } \\
0.86 \pm 0.18\end{array}$ & - & $\begin{array}{l}\text { Test } 98 \% \text {; } \\
\text { Control } \\
100 \%\end{array}$ & $\begin{array}{c}\text { Test: }-0.19 \pm 0.62 \mathrm{~mm} \text {; Control: } \\
-0.33 \pm 0.71 \mathrm{~mm}\end{array}$ \\
\hline Villarinho & 2017 & Clinical & $1.6 \pm 0.3 \mathrm{~mm}$ & & $91.3 \%$ & $0.3 \pm 0.5 \mathrm{~mm}$ \\
\hline Zadeh & 2017 & Anatomical & $\begin{array}{c}\text { Test: } 1.78 \text { (1.13 to } 2.8) ; \\
\text { Control: } 0.93(0.59 \text { to } \\
1.39)\end{array}$ & $\begin{array}{l}\text { Test: } 10.67 \\
\text { (6.8 to } 16.8) ; \\
\text { Control: } 10.19 \\
\text { (6.5 to } 15.3)\end{array}$ & $\begin{array}{l}\text { Test: } 96 \% \text {; } \\
\text { Control: } \\
99 \%\end{array}$ & Test: $0.04 \mathrm{~mm}$; Control: $-0.02 \mathrm{~mm}$ \\
\hline
\end{tabular}

The mean C/I-R was 1.77. MBL was calculated for three different groups: group A (C/I-R 0-0.99): $0.35 \mathrm{~mm}$, group B (C/I-R 1-1.99): $0.03 \mathrm{~mm}$, group C (C/I-R >2): $0.02 \mathrm{~mm}$. Di Fiore et al. (17) studied 108 implants retrospectively with a mean C/I-R of $2.21 \mathrm{~mm}$. The mean MBL reported was $1.42 \mathrm{~mm}$. Guljé et al. (18) analyzed 47 implants in a perspective study. The mean C/I-R was 2.14 with a MBL reported of $0.13 \mathrm{~mm}$. Hadzik et al. (19) studied perspectively 30 implants with an anatomical ratio of 1.69. MBL reported was $0.34 \mathrm{~mm}$. Hingsammer et al. (20) in a perspective study analysed 76 implants. The mean C/I-R was 1.70 with a MBL of $0.71 \mathrm{~mm}$. Lee et al. (21) studied retrospectively 175 implants with a mean C/I-R of $1.06, \mathrm{MBL}$ reported was $0.93 \mathrm{~mm}$. Malchiodi et al. (22) analyzed 280 implants in a perspective study. In the study was reported both the anatomical and the clinical ratio, that was respectively 1.84 and 2.08. The MBL calculated was $0.48 \mathrm{~mm}$. Mangano et al. (23) studied 68 implants perspectively. The mean C/ I-R was 1.70 . After 5 years of loading, a mean MBL of 0.38 and 0.48 was reported in the $\mathrm{C} / \mathrm{I}<2$ and $\mathrm{C} / \mathrm{I}>2$ groups, respectively. Naenni et al. (24) analyzed 96 implants in a perspective cohort study. The $6-\mathrm{mm}$ and the $10-\mathrm{mm}$ had a mean C/I-R of 1.75 and 1.04, respectively. The mean MBL calculated was $0.29 \mathrm{~mm}$ for the $6-\mathrm{mm}$ group, and $0.15 \mathrm{~mm}$ for the 10-mm group. Nunes et al. (25) studied 118 implants retrospectively. The mean $\mathrm{C} / \mathrm{I}-\mathrm{R}$ was 2.53 and the $\mathrm{MBL}$ calculated was $0.67 \mathrm{~mm}$. Pieri et al. (26) in a perspective study analyzed 61 implants with a mean C/I-R of $1.94 \mathrm{~mm}$. The MBL calculated at 2 years was $0.60 \mathrm{~mm}$. Ramaglia et al. (27) studied perspectively 78 implants with a mean C/I-R of 1.08. MBL at 5-year was calculated separately for the $\mathrm{C} / \mathrm{I}-\mathrm{R}<1$ and $\mathrm{C} / \mathrm{I}-\mathrm{R}>1$ group and was 0.653 and 0.287 $\mathrm{mm}$ respectively. Rossi et al. (28) in a perspective study confronted two groups of 30 implants each. The mean C/I-R for test and control group was 1.55 and 0.97 respectively. After 5-year loading MBL calculated was $0.14 \mathrm{~mm}$ for test group and $0.18 \mathrm{~mm}$ for control group. Schneider et al. (29) in a retrospective study analyzed 100 implants. In the study was reported both the anatomical and the clinical C/I-R of 1.04 and 1.48 respectively. The MBL calculated was $0.008 \mathrm{~mm}$. Sharmann et al. (30) analyzed perspectively two different groups of 47 implants each. The mean C/I-R reported was 0.86 for the control group and 1.48 for the test group. The mean MBL calculated after 3 years were 0.19 and 0.33 for the test and control groups respectively. Urdaneta et al. (31) in a retrospective study analyzed 326 implants with a mean C/I-R of 1.6. The mean MBL found was $0.33 \mathrm{~mm}$. Villarinho et al. (32) analyzed 46 implants 
Table 2 Studies included in the review-part 2

\begin{tabular}{|c|c|c|c|c|c|c|c|c|}
\hline Article & Type of study & Follow-up & $\begin{array}{l}\mathrm{N}^{\circ} \text { of patients } \\
\text { and implants }\end{array}$ & Localization & $\begin{array}{c}\text { Type of } \\
\text { prosthesis }\end{array}$ & Type of implant & Length & Diameter \\
\hline Anitua et al. & Retrospective & $\begin{array}{c}23.18 \pm \\
7.7 \text { months }\end{array}$ & $\begin{array}{l}34 \text { patients, } \\
45 \text { implants }\end{array}$ & Mandible & FDP & - & $5.5,6.5 \mathrm{~mm}$ & $\begin{array}{c}3,75,4.0 \\
4.5,5.0 \mathrm{~mm}\end{array}$ \\
\hline Birdi et al. & Retrospective & $\begin{array}{c}20.9 \text { months } \\
\text { (range, } \\
15.6-122.8 \\
\text { months) }\end{array}$ & $\begin{array}{l}194 \text { patients, } \\
309 \text { implants }\end{array}$ & $\begin{array}{l}\text { Maxilla and } \\
\text { mandible }\end{array}$ & Single crown & Bicon & $5.7,6.0 \mathrm{~mm}$ & - \\
\hline Blanes et al. & Perspective & 1 year & $\begin{array}{l}83 \text { patients, } \\
192 \text { implants }\end{array}$ & $\begin{array}{l}\text { Posterior } \\
\text { regions } \\
\text { mandible and } \\
\text { maxilla }\end{array}$ & $\begin{array}{l}\text { Ceramic-to- } \\
\text { metal fused } \\
\text { fixed partial } \\
\text { dentures or } \\
\text { single crown }\end{array}$ & ITI & $8.01+-1.45 \mathrm{~mm}$ & - \\
\hline Guljé et al. & Perspective & 12 months & $\begin{array}{l}37 \text { patients, } \\
47 \text { implants }\end{array}$ & $\begin{array}{l}\text { Maxilla and } \\
\text { mandible }\end{array}$ & Single crown & $\begin{array}{c}\text { Astra Tech } \\
\text { OsseoSpeed }\end{array}$ & $6 \mathrm{~mm}$ & $4 \mathrm{~mm}$ \\
\hline Hadzik et al. & Perspective & 36 months & $\begin{array}{l}30 \text { patients, } \\
30 \text { implants }\end{array}$ & Maxilla & $\begin{array}{l}\text { Cemented } \\
\text { single crown }\end{array}$ & OsseoSpeed & $6 \mathrm{~mm}$ & $4 \mathrm{~mm}$ \\
\hline $\begin{array}{l}\text { Hingsammer } \\
\text { et al. }\end{array}$ & Perspective & 20.52 months & $\begin{array}{l}30 \text { patients, } \\
76 \text { implants }\end{array}$ & $\begin{array}{l}\text { Maxilla and } \\
\text { mandible }\end{array}$ & Splinted crown & $\begin{array}{l}\text { NobelSpeedy } \\
\text { Groovy Shorty }\end{array}$ & $6.5 \mathrm{~mm}$ & $4 \mathrm{~mm}$ \\
\hline $\begin{array}{l}\text { Mangano } \\
\text { et al. }\end{array}$ & Perspective & 5 years & $\begin{array}{l}50 \text { patients, } \\
68 \text { implants }\end{array}$ & $\begin{array}{l}\text { Maxilla and } \\
\text { mandible }\end{array}$ & $\begin{array}{c}49 \text { single } \\
\text { crowns; } 9 \text { FDP }\end{array}$ & Leone & $6.5 \mathrm{~mm}$ & $5 \mathrm{~mm}$ \\
\hline Naenni et al. & Perspective & $5 \pm 0.7$ years & $\begin{array}{c}96 \text { patients (86 } \\
\text { after } 5 \text { years), } \\
96 \text { implants }\end{array}$ & $\begin{array}{l}\text { Maxilla and } \\
\text { mandible }\end{array}$ & Single crown & $\begin{array}{c}\text { Standard } \\
\text { Plus Tissue } \\
\text { Level Implant } \\
\text { (Straumann) }\end{array}$ & $\begin{array}{c}\text { Case: } 6 \mathrm{~mm} \text {; } \\
\text { Control: } 10 \mathrm{~mm}\end{array}$ & $4.1 \mathrm{~mm}$ \\
\hline Nunes et al. & Retrospective & 36 months & $\begin{array}{l}59 \text { patients, } \\
118 \text { implants }\end{array}$ & $\begin{array}{l}\text { Maxilla and } \\
\text { mandible }\end{array}$ & $\begin{array}{c}28 \text { single } \\
\text { crown; } 90 \\
\text { splinted } \\
\text { crowns }\end{array}$ & - & $7 \mathrm{~mm}$ & $4 \mathrm{~mm}$ \\
\hline Pieri et al. & Perspective & 2 years & $\begin{array}{l}25 \text { patients, } \\
61 \text { implants }\end{array}$ & Mandible & FDP & $\begin{array}{l}\text { OsseoSpeed } \\
\text { (Astra Tech) }\end{array}$ & $6 \mathrm{~mm}$ & $4 \mathrm{~mm}$ \\
\hline
\end{tabular}

Table 2 (continued) 
Table 2 (continued)

\begin{tabular}{|c|c|c|c|c|c|c|c|c|}
\hline Article & Type of study & Follow-up & $\begin{array}{l}\mathrm{N}^{\circ} \text { of patients } \\
\text { and implants }\end{array}$ & Localization & $\begin{array}{c}\text { Type of } \\
\text { prosthesis }\end{array}$ & Type of implant & Length & Diameter \\
\hline $\begin{array}{l}\text { Ramaglia } \\
\text { et al. }\end{array}$ & Perspective & 5 years & 78 implants & $\begin{array}{l}\text { Mandible and } \\
\text { maxilla }\end{array}$ & $\begin{array}{c}\text { Metal ceramic } \\
\text { crown }\end{array}$ & r & $\begin{array}{c}<10-\mathrm{mm} \text { long: } 35 \\
\text { implants; } \geq \\
\text { 10-mm long } \\
\text { (from } 10 \text { to } 15 \\
\text { mm): } 43 \text { implants }\end{array}$ & 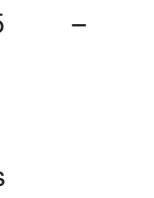 \\
\hline $\begin{array}{l}\text { Schneider } \\
\text { et al. }\end{array}$ & Retrospective & $\begin{array}{c}6.2 \text { years } \\
\text { (4.73 to } \\
11.7 \text { years) }\end{array}$ & $\begin{array}{l}70 \text { patients, } \\
100 \text { implants }\end{array}$ & $\begin{array}{l}\text { Maxilla and } \\
\text { mandible }\end{array}$ & Single crown & $\begin{array}{c}24 \text { Straumann, } 76 \\
\text { Branemark }\end{array}$ & $\begin{array}{l}11.5 \mathrm{~mm} \text { (7 to } \\
15 \mathrm{~mm})\end{array}$ & $\begin{array}{c}3.75- \\
4.1 \mathrm{~mm}: \\
66 \% ; 4.8- \\
5 \mathrm{~mm}: 34 \%\end{array}$ \\
\hline $\begin{array}{l}\text { Urdaneta } \\
\text { et al. }\end{array}$ & Retrospective & $\begin{array}{l}70.7 \pm 23 \\
\text { months }\end{array}$ & $\begin{array}{l}81 \text { patients, } \\
326 \text { implants }\end{array}$ & $\begin{array}{l}\text { Maxilla and } \\
\text { mandible }\end{array}$ & Single crown & Bicon & $\begin{array}{c}6 \mathrm{~mm} ; 8 \mathrm{~mm} ; 11 \\
\mathrm{~mm} ; 14 \mathrm{~mm}\end{array}$ & $\begin{array}{l}3.5 \mathrm{~mm} \\
4 \mathrm{~mm} \\
4.5 \mathrm{~mm} \\
5 \mathrm{~mm} \\
6 \mathrm{~mm}\end{array}$ \\
\hline $\begin{array}{l}\text { Villarinho } \\
\text { et al. }\end{array}$ & Perspective & $45 \pm 9$ months & $\begin{array}{l}20 \text { patients, } 46 \\
\text { implants }\end{array}$ & $\begin{array}{l}\text { Maxilla and } \\
\text { mandible }\end{array}$ & Single Crown & $\begin{array}{l}\text { Straumann } \\
\text { Standard Plus }\end{array}$ & $6 \mathrm{~mm}$ & $4.1 \mathrm{~mm}$ \\
\hline Zadeh et al. & Perspective & 3 years & $\begin{array}{l}95 \text { patients, } \\
209 \text { implants }\end{array}$ & $\begin{array}{l}\text { Maxilla and } \\
\text { mandible }\end{array}$ & FDPs & OsseoSpeed & $\begin{array}{c}\text { Test } 6 \mathrm{~mm} ; \\
\text { Control } 11 \mathrm{~mm}\end{array}$ & $4 \mathrm{~mm}$ \\
\hline
\end{tabular}

perspectively. The mean C/I-R reported was 1.6 with a MBL of $0.3 \mathrm{~mm}$. Zadeh et al. (33) analyzed perspectively for 3 years 209 implants divided in two groups. The C/I-R was 1.78 for the test group and 0.93 for the control group. The analysis of MBL revealed that the test group gained $0.04 \mathrm{~mm}$ while the control group losed $0.02 \mathrm{~mm}$. Overall, the highest follow-up reported was 16 years for the retrospective studies and 5 years for the prospective studies. The highest C/I-R reported was 2.5 .

Biomechanically, unfavourable ratio may influence marginal bone through the lever mechanism. When subjected to lateral forces, implant restorations with long lever arm generate greater stress at the bone crest. It has been demonstrated in a cantilever model that crown height increased from 10 to $20 \mathrm{~mm}$, lead to a proportional moment increment (34). C/I-R is calculated as the ratio between the crown and implant lengths. We can distinguish two different C/I-R:
* Anatomical ratio is the ratio between the distance from the apex to the shoulder of the implant, and the distance from the shoulder of the implant to the end of the crown;

* Clinical ratio is the ratio between the distance from the apex to the bone level, and the distance from the bone level to the end of the crown.

Clinical ratio is considered a more accurate since the implant-bone interface is less rigid than the connection at the implant shoulder, due to bone viscoelasticity (16). Among the studies included in this review, many concluded that the relationship between C/I-R and MBL is not significant. Urdaneta et al. (31) concluded that larger CI ratio led to an increase in prosthetic complications but had no significant influence on MBL. In this study $16 \%$ of the sample had CI ratio $>2$. Nunes et al. (25) found a weak inverse correlation between CI ratio and MBL. Blanes et al. (16) stated that there were no statistical 
relationship between CI ratio and MBL. Birdi et al. (15) found no significant relationship between CI ratio and first bone-to-implant contact levels. Schneider et al. (29) concluded that technical and biological CI ratio had no significant correlation on the MBL, technical and biological complications and implant survival. Mangano et al. (23) found no correlation between MBL and CI ratio along time, with a $0.023 \mathrm{~mm}$ increase in 1-year bone resorption for every 0.1 increase in CI ratio. However, other studies found a stronger correlation between C/I-R and MBL. Di Fiore et al. (17) showed that, at multivariable analysis, C/I-R $>2$ was correlated with higher MBL. It was estimated that $\mathrm{C} / \mathrm{I}-\mathrm{R}>2$ led to an increase of $0.28 \mathrm{~mm}$ in MBL. However, the authors underlined that this increment could be considered clinically irrelevant. Hingsammer et al. (20) concluded that a MBL of $0.71 \mathrm{~mm}$ is considered to be satisfactory and a C/I-R of 1.7 can be considered as a threshold to avoid early marginal bone changes. Malchiodi et al. (22) showed that implants with C/I ratio $>2$ had a MBL of $0.72 \mathrm{~mm}$. Statistical analysis revealed that both anatomical and clinical CI ratio had a correlation with MBL. The authors concluded that, from a biomechanical point of view, to avoid excessive bone loss, anatomical and clinical C/I ratio should not exceed respectively 3.1 and 3.4. It was seen that $\mathrm{C} / \mathrm{I}$ ratio resulted the main factor correlated to implant success and crestal bone loss.

The difference between all this findings can be found in various aspects. Many studies mixed together implants of different lengths; moreover, the definition of short implant is not standardized. Tawil and Younan considered short an implant $<10 \mathrm{~mm}$ (35). Nisand and Renouard defined "short" implants with a length of $<8 \mathrm{~mm}$ and extra-short the one $<5 \mathrm{~mm}$ (36). Since the length of the implant seems not to be correlated to the lever mechanism, the portion that may be significantly correlated is the crown. In many of the previous mentioned studies, the crown-height-space was not considered in relation to CI ratio. Anitua et al. (14) analysed 45 extra-short implants with a mean CI ratio of 2.4 and a mean CHS of 17.05. Results showed that implants with MBL $<2 \mathrm{~mm}$ had a mean CHS of $17 \mathrm{~mm}$, while implants with MBL >2 had a mean CHS of $21 \mathrm{~mm}$. Statistical analyses revealed that CHS had a positive correlation with bone loss. Nissan et al. (37) in an in vitro study showed that an increased crown height from 6 to $12 \mathrm{~mm}$, in case of off-axis loading of 30 degrees determined a proportional increase stress distribution (17.72 vs. $30.09 \mathrm{MPa}$ ). CHS higher than $15 \mathrm{~mm}$ is considered as biomechanically unfavourable, resulting in increased stress at bone level.
Failure were noted at CHS $>15 \mathrm{~mm}$ and CI ratio at 1.75 when force application was at 30 degrees. The authors concluded that CHS is more significant than CI ratio in the evaluation of the adverse effects related to biomechanics, and studies about the effects of C/I ratio should mention both implant length and CHS in their results.

In this review was considered both splinted and unsplinted implants. Many studies underline that splinting crowns together could better distribute non-axial forces, minimizing their load to the restoration and bone, and increasing the load area (7). Moreover, splinting is recommended in case of poor quality bone to be reduced the marginal bone stress under horizontal load (38). Therefore, splint implants could alter the real impact of $\mathrm{C} / \mathrm{I}-\mathrm{R}$ on MBL resulting in less cervical stress for a better forces distribution. However, in an in vitro study Nissan et al. (37) proved the splinting implants can result in greater crestal bone loss.

In conclusion, according to a recent consensus of EAO (39), is possible to state that crown-to-implant not exceed 2.2 did not influence the possibility of biological complications and lead to a not significant MBL. Further research should investigate the complications of higher ratios, the implications of splinted implants on forces distribution and the role of crown height on MBL.

\section{Acknowledgments}

Funding: None

\section{Footnote}

Reporting Checklist: The authors have completed the Narrative Review reporting checklist. Available at https://fomm. amegroups.com/article/view/10.21037/fomm-20-57/rc

Conflicts of Interest: All authors have completed the ICMJE uniform disclosure form (available at https://fomm. amegroups.com/article/view/10.21037/fomm-20-57/coif). The authors have no conflicts of interest to declare.

Ethical Statement: The authors are accountable for all aspects of the work in ensuring that questions related to the accuracy or integrity of any part of the work are appropriately investigated and resolved.

Open Access Statement: This is an Open Access article distributed in accordance with the Creative Commons 
Attribution-NonCommercial-NoDerivs 4.0 International License (CC BY-NC-ND 4.0), which permits the noncommercial replication and distribution of the article with the strict proviso that no changes or edits are made and the original work is properly cited (including links to both the formal publication through the relevant DOI and the license). See: https://creativecommons.org/licenses/by-nc-nd/4.0/.

\section{References}

1. Papaspyridakos P, Bordin TB, Natto ZS, et al. Complications and survival rates of 55 metal-ceramic implant-supported fixed complete-arch prostheses: A cohort study with mean 5-year follow-up. J Prosthet Dent 2019;122:441-9.

2. Pjetursson BE, Thoma D, Jung R, et al. A systematic review of the survival and complication rates of implantsupported fixed dental prostheses (FDPs) after a mean observation period of at least 5 years. Clin Oral Implants Res 2012;23:22-38.

3. Papaspyridakos P, Chen CJ, Singh M, et al. Success Criteria in Implant Dentistry: A Systematic Review. J Dent Res 2012;91:242-8.

4. Simons WF, De Smit M, Duyck J, et al. The proportion of cancellous bone as predictive factor for early marginal bone loss around implants in the posterior part of the mandible. Clin Oral Implants Res 2015;26:1051-9.

5. Rangert B, Krogh PH, Langer B, Van Roekel N. Bending overload and implant fracture: a retrospective clinical analysis. Int J Oral Maxillofac Implants 1995;10:326-34.

6. Brunski JB, Puleo DA, Nanci A. Biomaterials and biomechanics of oral and maxillofacial implants: current status and future developments. Int J Oral Maxillofac Implants 2000;15:15-46.

7. Kim Y, Oh TJ, Misch CE, et al. Occlusal considerations in implant therapy: clinical guidelines with biomechanical rationale: Occlusal consideration in implant therapy. Clin Oral Implants Res 2005;16:26-35.

8. Zurdo J, Romão C, Wennström JL. Survival and complication rates of implant-supported fixed partial dentures with cantilevers: a systematic review. Clin Oral Implants Res 2009;20:59-66.

9. Leung KC, Chow TW, Wat PY, et al. Peri-implant bone loss: management of a patient. Int J Oral Maxillofac Implants 2001;16:273-7.

10. Ozgur GO, Kazancioglu HO, Demirtas N, et al. Risk factors associated with implant marginal bone loss: a retrospective 6-year follow-up study. Implant Dent
2016;25:122-7.

11. Tawil G, Aboujaoude N, Younan R. Influence of prosthetic parameters on the survival and complication rates of short implants. Int J Oral Maxillofac Implants 2006;21:275-82.

12. Quaranta A, Piemontese M, Rappelli G, et al. Technical and biological complications related to crown to implant ratio: a systematic review. Implant Dent 2014;23:180-7.

13. Garaicoa-Pazmiño C, Suárez-López del Amo F, Monje A, et al. Influence of crown/implant ratio on marginal bone loss: a systematic review. J Periodontol 2014;85:1214-21.

14. Anitua E, Alkhraist M, Piñas L, et al. Implant Survival and Crestal Bone Loss Around Extra-Short Implants Supporting a Fixed Denture: The Effect of Crown Height Space, Crownto-Implant Ratio, and Offset Placement of the Prosthesis. Int J Oral Maxillofac Implants 2014;29:682-9.

15. Birdi H, Schulte J, Kovacs A, et al. Crown-to-Implant Ratios of Short-Length Implants. Journal of Oral Implantology 2010;36:425-33.

16. Blanes RJ, Bernard JP, Blanes ZM, et al. A 10-year prospective study of ITI dental implants placed in the posterior region. II: Influence of the crown-to-implant ratio and different prosthetic treatment modalities on crestal bone loss. Clin Oral Implants Res 2007;18:707-14.

17. Di Fiore A, Vigolo P, Sivolella S, et al. Influence of Crownto-Implant Ratio on Long-Term Marginal Bone Loss Around Short Implants. Int J Oral Maxillofac Implants 2019;34:992-8.

18. Guljé FL, Raghoebar GM, Erkens WA, et al. Impact of Crown-Implant Ratio of Single Restorations Supported by 6-mm Implants: A Short-Term Case Series Study. Int J Oral Maxillofac Implants 2016;31:672-5.

19. Hadzik J, Krawiec M, Sławecki K, et al. The Influence of the Crown-Implant Ratio on the Crestal Bone Level and Implant Secondary Stability: 36-Month Clinical Study. Biomed Res Int 2018;2018:4246874.

20. Hingsammer L, Watzek G, Pommer B. The influence of crown-to-implant ratio on marginal bone levels around splinted short dental implants: A radiological and clinical short term analysis. Clin Implant Dent Relat Res 2017;19:1090-8.

21. Lee KJ, Kim YG, Park JW, et al. Influence of crownto-implant ratio on peri-implant marginal bone loss in the posterior region: a five-year retrospective study. $\mathrm{J}$ Periodontal Implant Sci 2012;42:231.

22. Malchiodi L, Cucchi A, Ghensi P, et al. Influence of crown-implant ratio on implant success rates and crestal bone levels: a 36-month follow-up prospective study. Clin 
Oral Implants Res 2014;25:240-51.

23. Mangano F, Frezzato I, Frezzato A, et al. The Effect of Crown-to-Implant Ratio on the Clinical Performance of Extra-Short Locking-Taper Implants. J Craniofac Surg 2016;27:675-81.

24. Naenni N, Sahrmann P, Schmidlin PR, et al. fiveyear survival of short single-tooth implants $(6 \mathrm{~mm})$ : a randomized controlled clinical trial. J Dent Res 2018;97:887-92.

25. Nunes M, Almeida R, Felino A, et al. The Influence of Crown-to-Implant Ratio on Short Implant Marginal Bone Loss. Int J Oral Maxillofac Implants 2016;31:1156-63.

26. Pieri F, Aldini NN, Fini M, et al. Preliminary 2-year report on treatment outcomes for 6-mm-long implants in posterior atrophic mandibles. Int J Prosthodont 2012;25:279-89.

27. Ramaglia L, Di Spirito F, Sirignano M, et al. A 5-year longitudinal cohort study on crown to implant ratio effect on marginal bone level in single implants. Clin Implant Dent Relat Res 2019;21:916-22.

28. Rossi F, Botticelli D, Cesaretti G, et al. Use of short implants $(6 \mathrm{~mm})$ in a single-tooth replacement: a 5 -year follow-up prospective randomized controlled multicenter clinical study. Clin Oral Implants Res 2016;27:458-64.

29. Schneider D, Witt L, Hämmerle CHF. Influence of the crown-to-implant length ratio on the clinical performance of implants supporting single crown restorations: a crosssectional retrospective 5-year investigation: Influence of the $\mathrm{c} / \mathrm{i}$ ratio on the performance of implants supporting single crown restorations. Clin Oral Implants Res 2012;23:169-74.

30. Sahrmann P, Naenni N, Jung RE, et al. Success of 6-mm Implants with Single-Tooth Restorations: A 3-year Randomized Controlled Clinical Trial. J Dent Res 2016;95:623-8.

doi: $10.21037 /$ fomm-20-57

Cite this article as: Di Fiore A, Maniero F, Stellini E. The influence of crown-to-implant ratio on marginal bone loss: a narrative review. Front Oral Maxillofac Med 2020;2:29.
31. Urdaneta RA, Rodriguez S, McNeil DC, et al. The effect of increased crown-to-implant ratio on single-tooth locking-taper implants. Int J Oral Maxillofac Implants 2010;25:729-43.

32. Villarinho EA, Triches DF, Alonso FR, et al. Risk factors for single crowns supported by short (6-mm) implants in the posterior region: A prospective clinical and radiographic study: VILLARINHO et al. Clin Implant Dent Relat Res 2017;19:671-80.

33. Zadeh HH, Guljé F, Palmer PJ, et al. Marginal bone level and survival of short and standard-length implants after 3 years: An Open Multi-Center Randomized Controlled Clinical Trial. Clin Oral Implants Res 2018;29:894-906.

34. Misch CE, Goodacre CJ, Finley JM, et al. Consensus conference panel report: crown-height space guidelines for implant dentistry-part 2. Implant Dent 2006;15:113-21.

35. Tawil G, Younan R. Clinical evaluation of short, machinedsurface implants followed for 12 to 92 months. Int J Oral Maxillofac Implants 2003;18:894-901.

36. Nisand D, Renouard F. Short implant in limited bone volume. Periodontol 2000 2014;66:72-96.

37. Nissan J, Gross O, Ghelfan O, et al. The Effect of Splinting Implant-Supported Restorations on Stress Distribution of Different Crown-Implant Ratios and Crown Height Spaces. J Oral Maxillofac Surg 2011;69:2990-4.

38. Wang TM, Leu LJ, Wang J, et al. Effects of prosthesis materials and prosthesis splinting on peri-implant bone stress around implants in poor-quality bone: a numeric analysis. Int J Oral Maxillofac Implants 2002;17:231-7.

39. Hämmerle CHF, Cordaro L, Alccayhuaman KAA, et al. Biomechanical aspects: Summary and consensus statements of group 4. The 5th EAO Consensus Conference 2018. Clin Oral Implants Res 2018;29:326-31. 